\title{
„Autor to właśnie ja”: Gve Flaubert, czyli pisarz-rękopis ${ }^{\mathrm{I}}$
}

Fundamentalne pytanie dotyczące „pisarskiego powołania” Flaubert postawił sobie późno, mimo iż pisał od chwili, kiedy nauczył się pisać, a pierwsze listy do Ernesta Chevalier wysyłał już jako młody literat, mówiący o dziełach powstałych lub wspólnie projektowanych. U młodego Gustave'a dostrzec można nie tyle pragnienie, by zostać pisarzem, ile gotowość do bycia pismem, literackim tematem - jak święty Antoni - a wszystko to dzięki utożsamieniu się z rękopisem, z narzędziami skryby, gęsim piórem, atramentem, papierem. Słynna „przyjemność, jaka zawarta jest w materialnym akcie przepisywania”, doznawana ostatecznie przez Bouvarda i Pécucheta, patronuje zasadzie przyjemności młodego „człowieka-pióra”. Proponuję, by przez ten szczególny pryzmat spojrzeć na pierwsze teksty Flauberta. Rękopis stanowi nie tylko rodzaj przekazu, unikatowego za życia autora, ale jest też sposobem istnienia młodzieńczego pisania, pozwalającym, by ono samo mogło poddać się refleksji oraz spełnić. Jeśli dojrzewanie pisarza łączy się z dojrzewaniem książki, to w przypadku młodego Gustave'a bycie pisarzem jest tożsame z pragnieniem pozostania w kręgu prywatnym, intymnym, w kręgu autografu. Warto zatem przyjrzeć się narodzinom pisarza, w mniejszym stopniu wyrażającym je figurom alegorycznym (małpa, szaleniec, linoskoczek, kopista), bardziej zaś formom i modalnościom pracy z rękopisem, jedynym egzemplarzem, który miał taki pozostać, rejestrującym poszczególne zdarzenia i stawiającym opór typografii czyhającej na niego po śmierci.

I Podstawą thumaczenia jest tekst wygłoszony podczas konferencji „Devenir écrivain” i opublikowany w „Revue Flaubert” 2002, nr 2 (http://flaubert. univ-rouen.fr/revue/revue2/lecler.pdf). 
Przed trzydziestym piątym rokiem życia oraz Pania Bovary Flaubert nic nie opublikował. Z wyjątkiem - dość istotnym, ponieważ opowiedział o nim Goncourtom dwadzieścia lat później (Dziennik, 25 lutego 1860) - dwóch tekstów: baśni Bibliomanie oraz fizjologii kopisty Une leçon d' histoire naturelle. Genre commis, które ukazały się w roku 1837 w „Le Colibri”, niewielkim piśmie literackim wydawanym w Rouen. Co ciekawe, tematem obu tekstów oddanych do druku jest pismo ręczne i rękopis, bibliomania i grafomania. Kopista „pisze powoli, rozkoszując się zapachem atramentu i przyglądając się z przyjemnością, jak rozchodzi się po ogromnej kartce" ${ }^{2}$. Jeśli zaś chodzi o księgarza Giacomo, wyrusza on na poszukiwanie pierwszej drukowanej książki oraz starej, tajemnej księgi, która zachowała się tylko w jednym egzemplarzu: oczywiście to niepowtarzalność i oryginalność właściwe rękopisowi, w przeciwieństwie do powtarzalności druku, fascynują kolekcjonera.

Reszta, wiele tysięcy stron zaczernionych przed Pania Bova$r y$, narasta, nie budząc ze snu drukarskiej prasy. Dzięki temu Flaubert wiele lat później był zadowolony, że potrafił oprzeć się młodzieńczemu pragnieniu opublikowania „sentymentalnej ratatui”, która zamknęła jego młodość: „Listopad podzieli los L'Education sentimentale [chodzi o wersję powieści z 1845 roku] i pozostanie w mej tece na czas nieograniczony" 3 (list do Louise Colet z 28 października 1853). Jednak decyzja o nieogłaszaniu drukiem dzieł młodości nie wynika tylko z negatywnej oceny estetycznej wygłoszonej wiele lat później; ta decyzja jest wpisana w sam tekst lub raczej w paratekst, pojawia się na przykład we wstępie do pierwszej bajki filozoficznej Un parfum à sentir ou les Baladins, zredagowanym, jeśli dać wiarę sugerowanej chronologii, przed napisaniem tekstu (mamy tu więc decyzję aprioryczną, początkowy program): „Te kartki zapisane chaotycznie, bez porządku, bez stylu, muszą zostać pogrzebane w kurzu mojej szuflady" (s. 81). Muszą: czasownik modalny skazuje kartki na ten sam los, który stał się udziałem bohaterów bajki, będących ofiarami Ananke, ale w przeciwieństwie do linoskoczka skazanego na wygnanie czy Marguerite, brzydkiej kobiety doprowadzonej do szaleństwa i samobójstwa, rękopis narzuca sam sobie los rzeczy niewidzialnej, unika społeczne-

${ }^{2}$ G. Flaubert, Euvres complètes, vol. I, Euvres de jeunesse, édition de C. Gothot-Mersch et G. Sagnes, Gallimard: Collection de la Bibliothèque de la Pléiade, Paris 2001, s. 199. Jeśli nie podano inaczej, kolejne cytaty, lokalizowane w tekście głównym, pochodzą także z tego wydania. s. 156.

3 G. Flaubert, Listy, wyboru dokonał i przeł. W. Rogowicz, Warszawa 1957, 
go sądu, nie wstępuje na scenę, czyniąc wyjątek tylko dla kilku życzliwych czytelników.

Flaubert, jak wiadomo, także później podtrzymywał będzie tę odmowę druku, publikacji-prostytucji. Kilka cytatów - z początku i końca kariery - niech stanowi dowód godnej podziwu nieustępliwości w proteście, prewencyjnym (nie skuszą mnie) lub retrospektywnym (gdybym wiedział!): „Jeśli chodzi o pisanie, to założyłbym się, że nigdy nie będę drukował" (list do Ernesta Chevalier z 24 lutego 1839); „Jest prawie pewne, że nigdy nie dam do druku jednej linijki" 4 (list do Louise Colet z 23 października 1846); „Niech będzie przeklęty dzień, kiedy podjąłem nieszczęśliwą decyzję wydrukowania mojego nazwiska na książce! Nie ma co do tego wracać, niestety! Ale doprowadza mnie do rozpaczy to, że się mną zajmują" (list do Guy de Maupassant z 16 lutego $1879 \mathrm{w}$ związku z zapłatą wyproszoną dla niego przez przyjaciół).

Radykalne oddzielenie pisania od decyzji o druku, potwierdzane nawet dużo później, po publikacji książki, pociąga za sobą dwie praktyczne konsekwencje. Pierwsza - świętość krytyki genetycznej - dotyczy skrupulatnego przechowywania każdego śladu rękopiśmiennego, postrzeganego jako literacki odpowiednik parytetu złota, w porównaniu z którym wydrukowana książka jest tylko drobną monetą, nieuchronnym upadkiem; wspomniany ślad jest uznawany za współistotny wobec samego pisarza, pragnącego, by pochować go razem z rękopisami, zachowując przy tym wyobrażoną równoważność ciała (corps) i korpusu (corpus). Kartki, na których widać znak ręki, wolne są od wyroku, skazującego je na „pogrzebanie w kurzu” szuflady, na wzór pierwszej bajki, ale - dzięki logicznemu dopełnieniu funeralnej metafory - są ofiarowane wieczności, by ich proch przemieszał się z prochem ciała autora. Druga konsekwencja - rozpacz edytora - dotyczy niedbalstwa i nonszalancji, jaką Flaubert przejawiał w ostatniej fazie przekształceń procesu redakcyjnego w wydrukowaną rzecz: „Moja nienawiść do drukowania jest taka, że nie lubię wchodzić do drukarni i nie znam się na tym, jak się robi korektę odbitek" 5 (list do Eugène'a Crépet - prawdopodobnie z marca 1867). Flaubert okazuje się anty-Balzakiem: dla tego drugiego szpalta była czymś, co nieustannie ożywiało potrzebę rękopiśmiennej ekspansji, podczas gdy zaangażowanie pierwszego kończyło się, kiedy nie rozpoznawał już rzemieślniczego produktu własnych rąk.

\footnotetext{
4 Ibidem, s. 56.

5 Ibidem, s. 256.
} 
To prywatne pisanie pozostawiło $\mathrm{w}$ tekstach młodzieńczych wiele znaków, przede wszystkim manifestacyjnych deklaracji o braku ich przeznaczenia. Znaki te pojawiają się przede wszystkim w cyklu autobiograficznym, w przypadku którego to gatunek wymusza, by wypowiedź skierowana była ku autorowi, wzmacniając tym samym wolę ochrony intymności związanej $\mathrm{z}$ rękopisem. Wprowadzenie rozważań $\mathrm{w}$ pierwszej osobie, zebranych w Agonies, pozwala spojrzeć na ich autora z zewnątrz, by doprecyzować jego projekt: „Nigdy nie czynił tego z zamiarem późniejszej publikacji” (s. 398). [Cabier intime de 1840-1841] powtarza to samo pragnienie nieprzechodniości: „Chciałbym zrozumieć uczucie, nakazujące mi zapisywać te kartki, zwłaszcza tę, kartki tej nocy, których nie pozwolę nikomu przeczytać" (s. 747), i jeszcze deklaracja Narcyza odbitego w lustrze atramentu: „Piszę, by się czytać” (s. 741).

Istnienie rękopiśmienne wyklucza wszelkiego rzeczywistego i anonimowego czytelnika, a wykluczenie to jest tym bardziej wyraziste, że towarzyszy mu inflacja przeromantyzowanych apostrof do czytelnika wirtualnego, który musi takim pozostać. Jedynym faktycznym czytelnikiem tych autobiograficznych tekstów jest sam pisarz, łączący dwie role komunikacyjne: nadawcy i odbiorcy. Rękopis utrwala sądy autora zapisywane podczas kolejnych lektur na marginesach lub w obrębie tekstu. Młody pisarz, będący jeszcze uczniem, przyswaja sobie szkolną praktykę poprawiania kopii aż do tego stopnia, że jest zarazem wychowankiem i nauczycielem, autorem i swoim krytykiem. We wprowadzeniu do [Cabier intime de 1840-1841] początkowy fragment poświęcony nieskończoności jest podwójnie przekreślony ukośną linią i słowem „głupi” zapisanym na ukos (s. 729). Nieco dalej, po rozważaniach o demonie ciała, pojawia się w nawiasie wyrok: „żałosne” (s. 744), a pierwsza całość kończy się retrospektywnym spojrzeniem, utrwalonym na marginesie: „Przeczytałem ponownie ten zeszyt, mając litość dla siebie samego" (s. 740). Intymne zapiski opatrzone więc zostały wewnętrznym potępieniem ( $\mathrm{z}$ różnych powodów: estetycznych, intelektualnych, moralnych); zawierają także sądy na temat innych tekstów samego Flauberta. Jest to nieustanny proces złożony z wzajemnych oskarżeń krążących od rękopisu do rękopisu, co zamyka krąg prywatnego pisania. Diarysta $\mathrm{w}$ [Cabier intime de 1840-1841] notuje swe reakcje jako odbiorcy własnych dzieł, po upływie roku: „Ostatnio przeczytałem ponownie Smara: rozczarowanie, jakiego doznałem, było kompletne" (s. 741). To samo rozczarowanie pojawia się $\mathrm{w}$ zakończeniu rękopisu „dawnego misterium”: zawarte w nagłówku sformułowanie 
„Refleksja człowieka obojętnego na sprawe, który przeczytat to po roku" przekształca się $\mathrm{w}$ długie uzasadnienie rzeczowej krytyki, kończące się wyrokiem bez odwołania: „Żegnaj, najlepsza rada, jaką mogę ci dać, to byś nie pisał więcej. Jaśmin” (s. 615). Sąd nad rękopisem skazuje go oczywiście na kurz szuflady, ale dzięki temu chroni go też przed zniszczeniem. Powołanie pisarza w dialektyczny sposób łączy te fazy odrzucenia poprzez negację i zachowania w archiwum, będącym świadkiem narodzin pisarza. Dojrzewający pisarz bierze udział w grze krytyki, autokrytyki, ponownej lektury, niemal natychmiastowej lub odłożonej w czasie, ale zawsze skazującej: nie jesteś jeszcze tym, kim możesz lub chcesz być, nauczyciel, który cię poprawia i jest we mnie, udowadnia, że jesteś w położeniu terminującego ucznia. $\mathrm{W}$ tak sformułowanym wyroku pojawia się również rozdwojenie na pisarza i czytelnika, wyobrażonego autora i nieubłaganego krytyka, Gustave’a Flauberta i kwitnącego Jaśmina (imię poety mówiącego gwarą [zob. s. 1415], dźwiękowo przypominające pseudonim światowego krytyka, którego refleksje będą się wydawać za rok równie głupie, co wygwizdane dzisiaj „dawne misterium”). Ten dystans między sobą a sobą, zamiana pomyślana natychmiast jako upadek w nadchodzącej przyszłości, przygotowuje w oddali przejście do bezosobowości (autor martwy i zmartwychwstały dzięki zdolnościom krytyka) oraz do ogólnej ironii (instancja krytyczna poddana krytyce w Jaśminie, którego imię budzi śmiech). Pisarz włączył do dzieła wymiar refleksyjny: wymyka się on zewnętrznemu spojrzeniu ponownej lektury i marginalnym poprawkom, a poprzez to czasowi, który ma nadejść.

Dzieło młodości - tekst bez jasno wskazanego czytelnika, tekst przeczytany i poprawiony przez inną część samego autora wyraża dodatkowo swój rękopiśmienny sposób istnienia poprzez odwołania do własnego tworzywa. Nie chodzi przy tym o gatunek popularny w XVIII wieku, czyli narracyjną fikcję odnalezionego manuskryptu, ale o wskazywanie, najczęściej w paratekście, realnego charakteru narzędzi. W dedykacji Agonies wspomniane zostają „ubogie kartki” obecnie „ułożone w stos papieru”, ale już wkrótce porwane przez wiatr, zgodnie z życzeniem osoby zapisującej dedykację (s. 383). Banalny obraz poetycki okazuje się wartościowy dzięki metapoetyckiej wskazówce fizycznego stanu, w jakim znalazł się zbiór. Pierwszy rozdział Pamiętników szaleńca również przedstawia, $\mathrm{w}$ sposób nieco przerysowany, narzędzia ironicznej namiętności oraz samo pismo: „Przeleję na papier wszystko, co przyjdzie mi do głowy [...]. Ciąży mi jednak myśl, że zużyję całą paczkę gęsich piór, opróżnię butelkę atra- 
mentu" ${ }^{6}$. W rozdziale XV narzędzie wywołuje wybuch w nieco inny sposób, z wyraźnie dydaktycznym wytłumaczeniem kolażu-montażu wstawionego fragmentu:

Fragment, który za chwilę przeczytacie, był częściowo napisany w grudniu poprzedniego roku, zanim jeszcze postanowiłem spisać Pamiętniki szaleńca.

Ponieważ powinien być wyodrębniony, umieściłem go w ramie, która się zaraz pojawi...

Oto on ${ }^{7}$.

Claudine Gothot-Mersch miała okazję przyjrzeć się rękopisowi, a jej opis jest potwierdzeniem montażu: odmienne kolory i formaty papieru, inna paginacja kartek (s. 1350-1351). Narracja odwołuje się tu do realności własnych narzędzi; jeśli świat diegezy zawiera opowiadanie o swoim powstawaniu w sensie materialnym, włącznie z decyzjami o cięciu i wznowieniu, to dzieje się tak dlatego, że nie wyzwolił się on jeszcze z rękopiśmiennego sposobu istnienia. Granica między trybem rękopiśmiennym i alograficznym dzieła mogłaby przebiegać w zakończeniu Listopada: pamiętamy, że na ostatnich stronach przyjaciel narratora opowiada swoją śmierć - zgodnie z tradycją Wertera. Przejście od spowiedzi do opowiadania jest oznaczone odgraniczającym zdaniem: „Tutaj kończy się rękopis” (s. 821). Jeśli Listopad jest, jak twierdził Flaubert, „zamknięciem [jego] młodości”, to dlatego, że materializuje się w nim - za sprawą tego zdania i światła, które je poprzedza - linia rozdziału między rękopisem (to nie tylko Listopad kończy się w tym miejscu, ale całe dzieło młodości, którego nie można oddzielić od jego „immanentnego obiektu", jak mówi Genette) a narodzinami książki w rękach innego człowieka, który po śmierci autora może dysponować kartkami zgodnie z własnym przeświadczeniem, włączywszy w to decyzję o ich pośmiertnym losie w formie drukowanej.

Z rękopiśmiennej specyfiki juweniliów wynika również mocno rozwinięty, niemal gadatliwy paratekst. Nie zawsze był on przestrzegany przez edytorów, którzy pomniejszali znaczenie zawartych w nim wskazówek i usiłowali znormalizować dziwactwa układu typograficznego, usuwając to, czego nie można było w rękopisie zredukować. Paratekst, poza swą funkcją poświadczającą autentyczność autografu, jest strategicznym miejscem

${ }^{6}$ G. Flaubert, Pamiętniki szaleńca, przeł. P. Śniedziewski, „Literatura na Świecie" 2011, nr 7-8, s. 265.

7 Ibidem, s. 294. 
umożliwiającym śledzenie wyobraźni dorastającego pisarza dzięki zapisom pozostawionym na początku i na końcu tekstu. (Takie towarzyszące wypowiedzi znikną niemal zupełnie z dojrzałych dzieł albo przynajmniej ulegną znaczącym przekształceniom: wystarczy przyjrzeć się dokumentom dotyczącym procesu przeciwko Pani Bovary lub tym na temat kłótni wokół Salambo, dodanym przez autora do późniejszych wydań. Książka o niczym jest samowystarczalna, burzy mosty łączące ją ze światem zewnętrznym, zrywa wszelkie związki).

Paratekst składa się z czterech elementów:

\section{1) cytat na początku}

Większość młodzieńczych tekstów posiada epigraf. Najczęściej odsyła on do Rabelais'go, Montaigne'a iSzekspira. Spotykają się w nim starożytni (Owidiusz), klasycy (La Bruyère) i nowożytnicy (Hugo, Dumas). Proces stawania się pisarzem wymaga, by kandydat wszedł $\mathrm{w}$ związek pokrewieństwa, by rozpoznał siebie dzięki hołdowi lub wdzięczności albo też - wprost przeciwnie - dzięki radykalnej obcości, by ujawnił referencje i preferencje, stworzył osobistą bibliotekę, w której będziemy szukać nie „źródeł”, ale ustanowionych figur, Ojców (Pères) stających się parami (pairs), elementów zapożyczonych zdań będących miarą dla fragmentów dzieła aspirującego do całości. Do autorów tworzących prywatny Panteon, prezentowanych niczym godło, dodać należy nazwiska pojawiające się w tekście: Byron, Sade, zwłaszcza Balzac - przywoływany dwa razy: Adèle de Monville zamyka się w salonie, by czytać „powieść Balzaca” („Quidquid volueris”, s. 267), a w „Małej komedii mieszczańskiej” pomieszczonej w utworze Smar pojawia się odesłanie w postaci definicji: „Miesiąc miodowy (zajrzeć do Filozofii [sic] małżéstwa pana Balzaca, by poznać kolejne fazy życia małżeńskiego)" (s. 580). Oto pośrednik przyłapany na fałszywym tropie, ukazany jako zaprzeczenie wzoru, skompromitowany w rytuale mieszczańskiej lektury i romantycznego komunału. Flaubert jest tu bezceremonialny. Znany jest jego dwuznaczny stosunek do starszego pisarza: wstępuje na jego terytorium (Flaubert zaczyna podróż po Bretanii w Anjou), by potem intensywnie pracować nad usuwaniem elementów balzakowskich.

\section{2) dedykacja}

Wiele tekstów opatrzonych jest dedykacją, w której ogólne dedykowanie dzieła miesza się z dedykowaniem konkretnego egzemplarza aż do tego stopnia, że dedykacja może być całkowitym 
i definitywnym ofiarowaniem rękopisu. Tak dzieje się w Pamiętnikach szaleńca, zadedykowanych, podobnie jak Agonies oraz Les Funérailles du Docteur Mathurin, bliskiemu przyjacielowi Alfredowi Le Poittevin: „Tobie, drogi Alfredzie, kartki te dedykuję i ofiarowuję" ${ }^{8}$ (s. 465). I rzeczywiście, Flaubert nie odzyska za życia tych kartek, które syn Alfreda, Louis Le Poittevin, przekaże bibliofilowi Pierre'owi Dauze, dzięki czemu zostaną one po raz pierwszy opublikowane w latach 1900-1901.

Dedykacja jest także wysyłką w znaczeniu epistolarnym, a osoba, której dedykowany jest utwór, staje się odbiorcą. U młodego Flauberta listy i teksty pozostają we wzajemnych relacjach. W pewnym sensie wysyła on listy wypełnione innymi tekstami, pisze do kogoś, by pisać z tym kimś, przekształcając odbiorcęczytelnika we współautora, a ciagła wymiana epistolarna przypominać zaczyna pisanie na dwie ręce: „Wyślę ci zeszyty, które wczoraj zacząłem zapisywać, bardzo cię proszę, byś mi je odesłał, a jeśli dopiszesz coś od siebie, sprawisz mi tym wielką przyjemność" (list do Ernesta Chevalier z lutego 1831). Od dzieciństwa (aż po starość Bouvarda i Pécucheta) zagadnienie stawania się pisarzami wyrażane jest w składni Flauberta w liczbie mnogiej, jest marzeniem o „podwójnym zaangażowaniu”.

$\mathrm{Z}$ drugiej strony, niektóre $\mathrm{z}$ juweniliów przyjmują formę epistolarną, zwłaszcza Agonies, którą można analizować jako ciąg listów lub bilecików wsuwanych do kolejnych kopert, w sumie trzech, przy czym każda kierowana jest do jednego odbiorcy, Alfreda, do którego nazwiska dołączany jest coraz bardziej rozwinięty „adres” (s. 382, 282, przypis na s. 1324). Rękopis [Cabier intime de 1840-1841] ma nawet ślady czerwonej pieczątki, jakby był listem zaadresowanym do siebie samego.

\section{3) data}

Teksty młodzieńcze, podobne w tym do listów, są także datowane - od pierwszego, Louis XIII, zadedykowanego: „Mojej matce, 28 lipca 1831", aż po Szkołę uczuć, opatrzoną w ukończonej postaci wzmianką: „Noc z 7 stycznia 1845, godzina pierwsza”, z Listopadem pośrodku, w którego finale pojawia się informacja „25 listopada 1842”, odsyłająca do tytułu z dokładnością niemal co do dnia. Czasami powtórzona data okala tekst, jak w Passion et vertu, gdzie strona tytułowa określa czas: „Listopad-grudzień 1837”, a ostatnia kartka wskazuje moment zakończenia: „10 grudnia 1837”. Rytm fragmentów składających się na Agonies jest wyznaczany przez trzykrotne powtórzenie tej samej

8 Ibidem, s. 263. 
daty - 20 kwietnia 1838 - po sygnaturze nadawcy, na początku i na końcu dziewięciu ponumerowanych myśli, by podkreślić jedność czasu wyznaczoną ramą dnia. Praktyka datacji zbliża młodzieńcze teksty do gatunków poddanych władzy kalendarza, do dziennika intymnego, listu i szkolnych ćwiczeń, od których pierwsze teksty odróżniają się z trudnością (przede wszystkim od cyklu historycznego). Młody autor pisze w niedzielę (co wyraźne jest 10 grudnia 1837) lub podczas wakacji, a jego swobodna twórczość zachowuje związki z instytucjonalnym wymogiem obowiązku szkolnego, zwłaszcza gdy historię wykłada Chéruel, uczeń Micheleta, a francuski - Gourgaud-Dugazon, wystarczająco bliski, by Flaubert zwierzył mu się z literackiego powołania.

Dzięki chronologii młody twórca wpisuje się w czas, archiwizuje, zachowuje pamięć siebie. Utrwala datę, ustala spotkania w mniej lub bardziej odległym terminie, czyniąc szalony zakład: kto przeczyta pewnego dnia te młodzieńcze linie, będzie wielkim człowiekiem. Taka projekcja przyszłości pojawia się dwukrotnie w [Cabier intime de 1840-1841], w czasie, kiedy Alfred, wyjechawszy do Paryża, pozbawił diarystę jedynego odbiorcy. A zatem Flaubert zwraca się do siebie samego: „Zapisuję te strony, by potem je przeczytać, za rok, za trzydzieści lat. To mnie przeniesie w czasy młodości” (s. 733). I dalej, w zakończeniu intymnych zeszytów:

Przypominam sobie, że Pan Cloquet [...] zasugerował pewnego dnia, bym zapisał w formie aforyzmów moje refleksje, zapieczętował je i otworzył po piętnastu latach. „Odnajdzie Pan innego człowieka”, powiedział. To może być dobra rada, posłucham jej (s. 749).

Nie wiadomo, kiedy oraz przez kogo pieczęć została zerwana, ponieważ także te kartki, o czym wspomniałem, noszą ślady czerwonego wosku. Trzeba stwierdzić, że Flaubert nie zapomniał o spotkaniach, które sobie wyznaczył: piętnaście lat po tych aforyzmach, napisanych w roku 1841, ukazała się Pani Bovary (1856); w pierwszym cytacie, Gustave proponuje sobie ponowną lekturę kartek, pochodzących nawet z roku 1839, zaś trzydzieści lat później, a więc w 1869, pojawia się Szkoła uczuć. Flaubert nie myli się nawet wówczas, gdy chodzi o terminy.

Czasowość objawia się w paratekście młodzieńczych rękopisów w inny jeszcze sposób: nie pod postacią zewnętrznej chronologii, ale we wskazówkach dotyczących trwania i rytmu zapisów. Gustave rejestruje swe działania w formie szyfrowanych świadectw inspirowanych romantyzmem. Rękopis La Femme du monde zawiera wzmiankę: „W nocy z 1 na 2 czerwca 1836. Zrobione w mniej niż pół godziny" (s. 130). Ten tekst zajmuje sześć 
stron w wydaniu Plejady: czas kompozycji miesza się więc z czasem potrzebnym do wykonania kopii, za jednym zamachem. W zakończeniu Un parfum à sentir ou les Baladins znalazł się obraz marszu (przymusowego), zaplanowanego w następujący sposób: „Pierwszy rozdział, napisałem go w ciągu jednego dnia; potem nie pracowałem przez miesiąc; $w$ ciągu tygodnia napisałem pięć kolejnych, a w dwa dni skończyłem" (s. 112) - a więc sześć ostatnich rozdziałów zostało zamkniętych $\mathrm{w}$ dwa dni.

To był okres (szczęśliwy?), kiedy tekst płynął niczym krew $\mathrm{w}$ żyłach, zgodnie z często pojawiającą się w tej epoce metaforą (w Listopadzie i w Szkole uczuć z roku 1845). Być pisarzem znaczy być natchnionym poetą, pisać tak szybko, jak się rozumuje, szybkości myśli odpowiada upragniona trafność wyrażenia, pisze się od razu i definitywnie. Rękopisy są dowodem tej swawoli: pozbawione szkiców młodzieńcze teksty nie mają genezy ani następujących po sobie etapów. Jak listy, wysyła się je w jednym egzemplarzu, są czytelne $\mathrm{w}$ formie, $\mathrm{w}$ jakiej powstały. Młody Gustave-poeta zachowuje te wyjątkowe rękopisy jako świadków romantycznego natchnienia. Artysta, a nawet rzemieślnik, Flaubert będzie je wciąż przechowywał, w wielowarstwowej masie, jako etyczny i estetyczny dowód „skomplikowanej mechaniki”. Ten odruch archiwizacji z różnych powodów obejmuje całe stulecie i wykracza poza przypadek Flauberta, kształtuje kulturowy dualizm, znajdujący się u podstaw zainteresowania - żywego przez cały XIX wiek - tymi kawałkami papieru, dzięki którym romantycy, a potem „realiści” postrzegali siebie jako proroków piszących pod dyktando lub jako wyrobników pióra.

\section{4) sygnatura}

G Flaubert. Gv Flaubert. Gve Flaubert. Sygnatura autora pojawia się wszędzie i wielokrotnie w obrębie tekstu, na stronie tytułowej, w zakończeniu dedykacji, na końcu wstępu i na końcu utworu. Nigdy imię Gustave nie występuje samotnie; nawet pierwszy, rodzinny tekst, zadedykowany matce, jest podpisany: G. Flaubert, a młodzieńcze listy sygnowane są: Flaubert, G Flaubert lub Gustave Flaubert. Czy to pozostałości szkolnego przyzwyczajenia? A może już sygnał ambicji, by mieć nazwisko, graficzne marzenie formującego się pisarza? Verso ostatniej kartki Bibliomanie posłużyło jako miejsce prób graficznych i piśmiennych: znalazły się na nim dwa portrety narysowane ołówkiem, cztery zarysy w formie gruszki, które doprowadziły do powstania słynnej karykatury Ludwika Filipa, inna wersja tytułu: „Le Bibliophile”, i dwie różne sygnatury Flauberta. Na tej wolnej przestrzeni pisarz usiłował nie tylko zmienić swój tytuł, ale i for- 
mę parafki. W druku sygnatura znikła, zastąpiona standardową czcionką nazwiska na okładce. Tylko rękopiśmienny oryginał naprawdę pozwala na wielorakie ukazanie osoby, która pisze.

A więc „Gv Flaubert” jest pisarzem, ponieważ dzieło młodości zasadza się na jego rękopiśmiennym charakterze.

By stał się pisarzem, którym był, musiały zniknąć lub zmienić kierunek elementy paratekstowe, skrywając materialność rękopisu (przynajmniej aż do czasu Bouvarda $i$ Pécucheta, gdzie widzialne narzędzia do pisania powracają z całą siłą).

Początkowe cytaty znikają. Nazwiska autorów będą związane tylko z wyobraźnią bohaterów (Emma, Fryderyk), a nie z pragnieniem pisarskim.

Dedykacja pojawia się tylko na początku Pani Bovary. Zaś ta $\mathrm{z}$ Kuszenia śrwiętego Antoniegoz roku 1872, dla wiecznego Alfreda, wskrzesza najważniejszą osobę, której dedykowane były dzieła młodości. Ale ta osoba już nie żyje. Zresztą, dla Flauberta adresat dedykacji jest dobry wówczas, gdy jest martwy. Albo dokładniej - to śmierć kogoś bliskiego tworzy idealnego odbiorcę dedykacji, mimo iż niezapisanego: Szkota uczuć z roku 1869 dla Sainte-Beuve'a, Czyste serce dla George Sand, wreszcie Bouilhet, który nie mógł towarzyszyć choćby jednej sylabie Bouvarda.

$\mathrm{Z}$ tekstu tworzonego $\mathrm{z}$ perspektywy bezczasu lub uwiecznienia teraźniejszości pisania znikają też daty.

Sygnatura staje się społecznym znakiem produktu, przestaje być śladem podmiotu i okazuje się prawnym „poręczycielem” czynu podlegającego sądom, poprawczym lub literackim. Można by bezceremonialnie prześledzić kolejne etapy zaniku imienia. $\mathrm{Na}$ początku sława jest wyobrażana $\mathrm{w}$ teatralnej formie bohatera na scenie: „Wzywają autora - autor - autor to właśnie ja, to moje imię - ja - ja - Poszukują mnie w korytarzach, w lożach - pochylają się, by mnie zobaczyć - kurtyna się podnosi, ja się zbliżam - jakie upojenie!” (s. 732 [interpunkcja zrekonstruowana według rękopisu]). Nawet jeśli uda się wyciągnąć autora zza kulis, nie prosi on o nic więcej, lecz tylko o to, by mógł tam wrócić, albo schronić się w budce suflera czy zająć miejsce zarezerwowane dla Deus absconditus. Prawa gatunkowe teatru sprawiają, że autor musi zniknąć w przedstawieniu. Potem autor dzieli się w podwójnej strukturze pisania na dwie ręce, odgrywając na przemian rolę nadawcy i odbiorcy, rozpada się na ja / on w ostatnim fragmencie Listopada. Wreszcie znika w zakończeniu [Cabier intime de 1840-1841] : „- Żegnaj Gustave”, jedyny przypadek, kiedy pojawia się imię, jakby przez uszanowanie dla tego, co osobiste, względne. 
Rękopis przetrwał jako wsparcie unikatowego, absolutnego gestu, a wraz z nim styl pospieszny, płynący z inspiracji, nazywany przez Flauberta „wrodzonym”. Młody Gustave jest pisarzem. Potem się nim staje, nie mogąc zakończyć - z powodu mnogości rozpoczynanych na nowo szkiców - tego procesu albo raczej nie potrafiąc przestać się mierzyć z niemożliwością powołania.

\section{Przet. Piotr Śniedzieweski}

\section{YVAN LECLERC \\ "I myself am the author": Gve Flaubert, or writer-manuscript}

The article attempts to present and discuss the juvenile works of Gustave Flaubert. Though the writer never allowed these juvenile works to be published, being extremely critical of their aesthetic value, the works such as November, Memoirs of a Madman or the diary-form Cabier intime de 1840-1841 still make important texts that provide a sizeable amount of information on the writer's literary workshop. Interestingly enough, these early works show the writer's attachment to the manuscript (tantamount to the dislike to the written word) and the author's tools (pen, ink and paper). These juvenile attempts, in the main autobiographical in nature, are thus penetrated by the metatext element that is a key input in providing an opportunity for a reflection on the way the text itself does exist: this element also informs us on Flaubert's growing maturity that ultimately defined his role of a fully-fledged author. The paratext elements (epigraphs, dedications, inscriptions, dates and signatures) in his juvenile works seem to be just as important as they allow us to follow, step by step, the way to the birth of a writer-manuscript and thus a writer who gets his fulfillment and the very existence exclusively in a text of a manuscript character.

Key words: Gustave Flaubert, manuscripts, juvenile literature, genetic criticism.

\footnotetext{
Yvan Leclerc - profesor na wydziale literatury Université de Rouen. Kieruje Centre Flaubert, które jest częścią pracowni CÉRÉdI (Centre d'études et de recherche Éditer-Interpréter). Jest odpowiedzialny za stronę poświęconążyciu i twórczości Flauberta (http:/ / flaubert.univ-rouen.fr). Jego badania oraz działalność wydawnicza są związane głównie z rękopisami i korespondencją Flauberta. Opracował m.in. G. Flaubert, Correspondance, Bibliothèque de la Pléiade, t. V oraz Indeks (2007). Dyrektor administracyjny pełnego wydania rękopisów Pani Bovary w Internecie (2009, http: / / www.bovary.fr) oraz rękopisów pierwszego tomu Bouvarda i Pécucheta (będą dostępne pod koniec 2012 roku).
} 
Piotr Śniedziewski - adiunkt w Zakładzie Literatury Romantyzmu Instytutu Filologii Polskiej UAM w Poznaniu, stypendysta rządu francuskiego (2003-2006 oraz 2009), Fundacji na rzecz Nauki Polskiej (2007) oraz Ministra Nauki i Szkolnictwa Wyższego (2011-2014). Autor książek Mallarmé - Norwid. Milczenie i poetycki modernizm we Francji oraz w Polsce (wydanie polskie: 2008; wydanie francuskie: 2009), Melancholijne spojrzenie (2011) i nowego przekładu Kuşzenia świętego Antoniego Gustave’a Flauberta (2010). Współredaktor pisma „Poznańskie Studia Polonistyczne. Seria Literacka”. e-mail: piotrsd@amu.edu.pl 
